\section{Growth and Carbon Partitioning in Cranberry Uprights as Influenced by Nitrogen Supply}

\author{
Justine E. Vanden Heuvel ${ }^{1}$ \\ University of Massachusetts Amherst, Cranberry Experiment Station, 1 State \\ Bog. Road, P.O. Box 569, E. Wareham, MA 02538
}

\author{
Joan R. Davenport \\ Washington State University, Irrigated Agriculture Research and Extension \\ Center, 24106 N. Bunn Road., Prosser, WA 99350
}

Additional index words. Vaccinium, photosynthesis, starch

\begin{abstract}
Information on growth and carbon partitioning of cranberry uprights in response to soil $\mathrm{N}$ application is lacking. Therefore, two experiments were initiated on 'Stevens' uprights to determine the effect of soil-applied $\mathbf{N}$ on tissue $\mathbf{N}$, growth, net carbon exchange (NCER), and nonstructural carbohydrate production of uprights of 'Stevens' cranberry. Tissue $\mathbf{N}$ concentration increased linearly with increasing soil $\mathbf{N}$ but was greater in vegetative uprights than in fruiting uprights. Current season growth on vegetative uprights was more responsive to tissue $\mathbf{N}$ than on fruiting uprights. Although chlorophyll concentration and NCER increased with increased soil N, upright starch concentration and often total nonstructural carbohydrate concentration decreased with increased soil $\mathbf{N}$ at midfruit development and preharvest, especially in vegetative uprights.
\end{abstract}

vegetative growth (measured as pruning biomass) associated with increasing $\mathrm{N}$ rate (Davenport and Vorsa, 1999). In general, higher yielding hybrid cultivars such as Stevens reach this point of optimal yield without excessive vegetative growth between 44 and $67 \mathrm{~kg} \cdot \mathrm{ha}^{-1} \mathrm{~N}$ fertilizer rates (Davenport and DeMoranville, unpublished data; Davenport and Vorsa, 1999; Hart et al., 1990).

In cranberry, studies have addressed the role of nonstructural carbohydrates $(\mathrm{CHO})$ in vegetative and reproductive production (Birrenkott and Stang, 1990; Birrenkott et al., 1991; Hagidimitriou and Roper, 1994; Vanden Heuvel and Davenport, 2005) without considering $\mathrm{N}$ nutrition. However, insufficient $\mathrm{N}$ has been implicated as playing a prominent role in limiting vegetative and reproductive growth in other fruit crops such as apple (Cheng and Fuchigami, 2002) and grapes (Cheng et al., 2004). The respective roles that insufficient $\mathrm{N}$ and $\mathrm{CHO}$ play in determining fruit production and vegetative growth in cranberry are unknown. Because leaves do not drop off from cranberry vines in the fall (like they do on other temperate fruit species such as grape), we suggest that $\mathrm{N}$ mobilization in the vine is not limited by the cool climate, although $\mathrm{N}$ concentration in
The American cranberry (Vaccinium macrocarpon Ait.) is a low-growing, vinelike woody perennial that forms a dense mat on the soil surface. Short vertical stems (i.e., uprights) bear fruit biennially, but as a result of the large population of uprights on a cranberry bed, overall yield does not usually alternate (Roper and Vorsa, 1997). The most important component of cranberry yield is fruit set (Baumann and Eaton, 1986). Lack of carbohydrate resources during fruit set is thought to result in failure of development of upper fruit on an upright (Birrenkott and Stang, 1990). Low fruit set (Roper and Vorsa, 1997), biennial bearing (Birrenkott et al., 1991; Strik et al., 1991), and low carbohydrate concentrations at the beginning of fruit set (Botelho and Vanden Heuvel, 2006; Hagidimitriou and Roper, 1994) all indicate continued carbohydrate stress in cranberry.

The role of nitrogen $(\mathrm{N})$ with respect to optimizing fruit production has been extensively studied in cranberry. Soils, climatic conditions, and cultivar (native selection vs. hybrid) influence cranberry response to $\mathrm{N}$ fertilizer rate (Davenport et al., 2000). The general trend is a partial parabolic curve in which yield increases with increasing $\mathrm{N}$ rate then begins to decline (Davenport et al., 2000) with a concomitant linear increase in

\footnotetext{
Received for publication 8 Jun. 2006. Accepted for publication 23 Jul. 2006.

We gratefully acknowledge the technical assistance of Amber Awad, Michelle Botelho, and Kelly Whitley.

${ }^{1}$ To whom reprint requests should be addressed; e-mail justinev@umext.umass.edu.
}
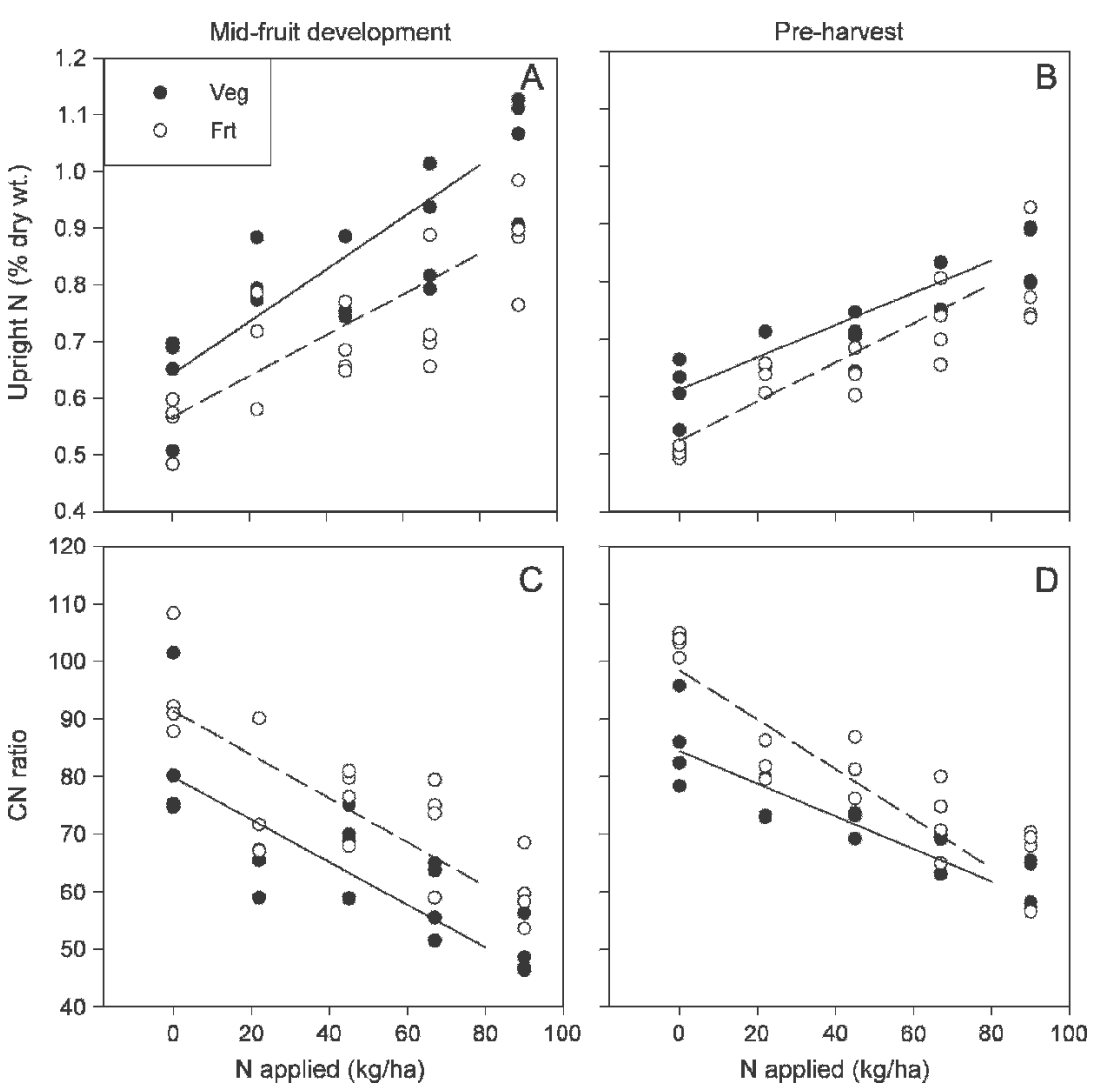

Fig. 1. The effect of soil-applied $\mathrm{N}$ on Stevens uprights in 2004. (A) N concentration at midfruit development, vegetative uprights $(\bullet): \mathrm{Y}=0.64+0.0046 \mathrm{x}, \mathrm{r}^{2}=0.6765$, fruiting uprights $(\mathrm{O}): \mathrm{Y}=0.57+$ $0.0036 \mathrm{x}, \mathrm{r}^{2}=0.6267$. (B) N concentration at preharvest, vegetative uprights $(\bullet): \mathrm{Y}=0.61+0.0028 \mathrm{x}, \mathrm{r}^{2}=$ 0.7740 , fruiting uprights $(\mathrm{O}): \mathrm{Y}=0.52+0.0034 \mathrm{x}, \mathrm{r}^{2}=0.7829$. (C) $\mathrm{CN}$ ratio at midfruit development, vegetative uprights $(\bullet): \mathrm{Y}=79.85-0.369 \mathrm{x}, \mathrm{r}^{2}=0.6486$, fruiting uprights $(\mathrm{O}): \mathrm{Y}=91.37-0.381 \mathrm{x}, \mathrm{r}^{2}=$ 0.6399 . (D) CN ratio at preharvest, vegetative uprights $(\bullet): \mathrm{Y}=84.39-0.283 \mathrm{x}, \mathrm{r}^{2}=0.7530$, fruiting uprights $(\bigcirc)$ : $\mathrm{Y}=98.43-0.430, \mathrm{r}^{2}=0.8206$. 
Bloom
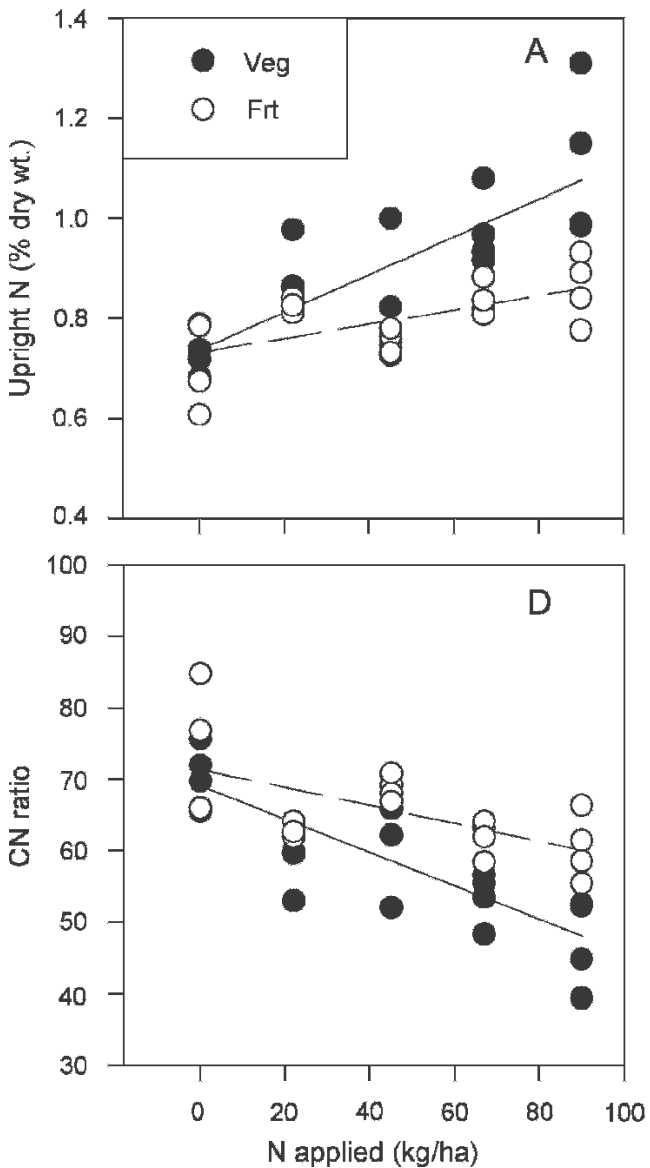

Mid-fruit Development
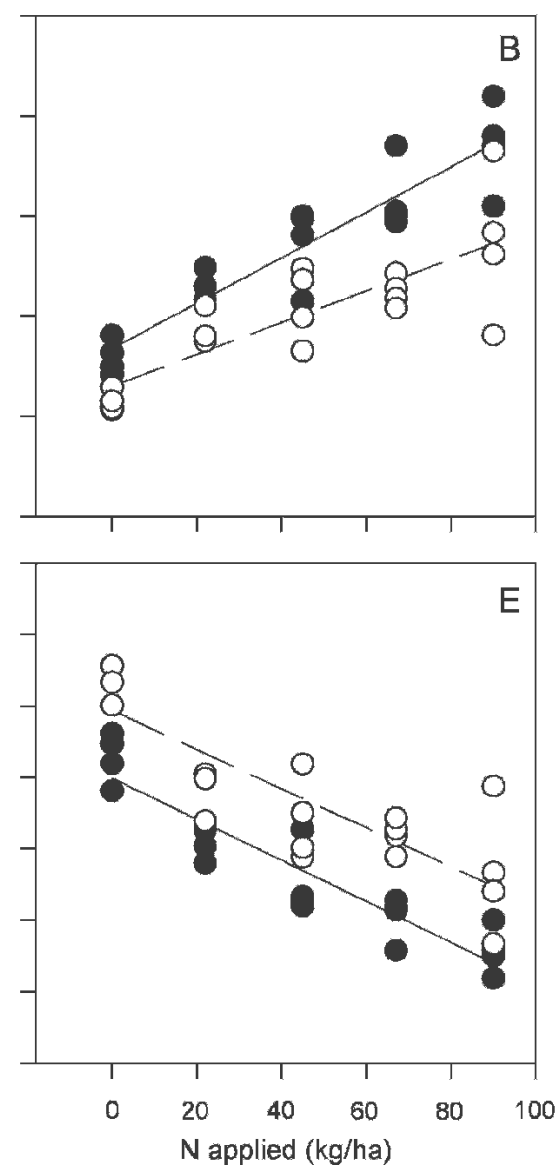

Pre-harvest
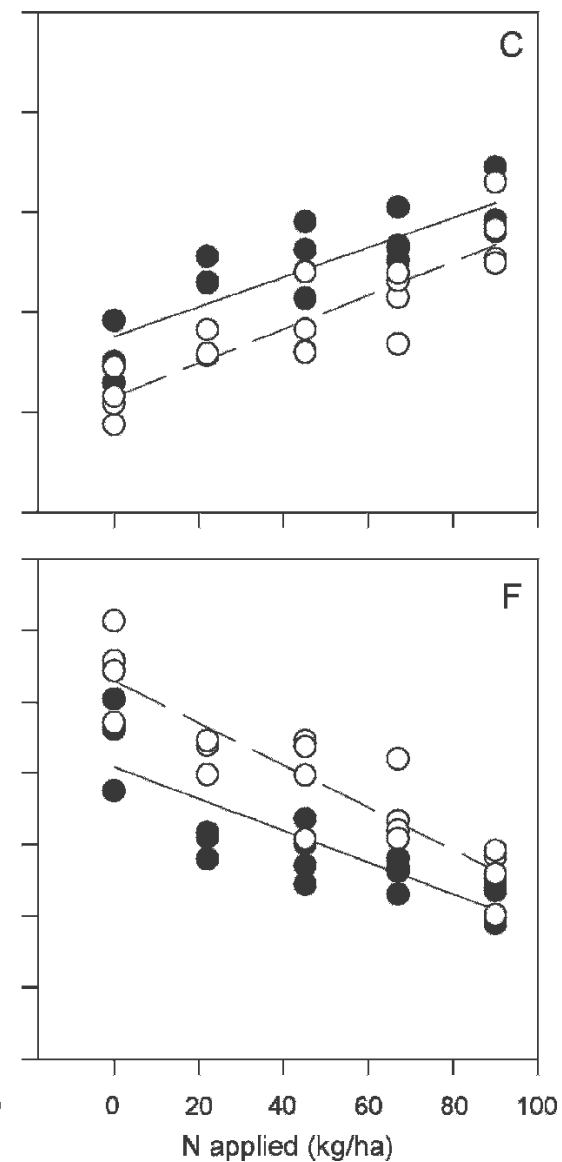

Fig. 2. The effect of soil-applied $\mathrm{N}$ on Stevens uprights in 2005. (A) N concentration at bloom, vegetative uprights $(\bullet): \mathrm{Y}=0.737+0.004, \mathrm{r}^{2}=0.5923$, Fruiting uprights $(\mathrm{O})$ : $\mathrm{Y}=0.732+0.002, \mathrm{r}^{2}=0.3896$. (B) $\mathrm{N}$ concentration at midfruit development, vegetative uprights $(\bullet): \mathrm{Y}=0.736+0.005 \mathrm{x}, \mathrm{r}^{2}=0.8552$, fruiting uprights $(\mathrm{O}): \mathrm{Y}=0.660+0.003 \mathrm{x}, \mathrm{r}^{2}=0.6500$. (C) $\mathrm{N}$ concentration at preharvest, vegetative uprights $(\mathbf{O}): \mathrm{Y}=0.752+0.003 \mathrm{x}, \mathrm{r}^{2}=0.7423$, fruiting uprights (O): $\mathrm{Y}=0.631+0.003 \mathrm{x}, \mathrm{r}^{2}=0.7835$. (D) $\mathrm{CN}$ ratio at bloom, vegetative uprights $(\bullet): \mathrm{Y}=69.14-0.233, \mathrm{r}^{2}=0.6259$, fruiting uprights $(\mathrm{O}): \mathrm{Y}=71.41-0.125$, $\mathrm{r}^{2}=0.3819$. (E) $\mathrm{CN}$ ratio at midfruit development, vegetative uprights $(\mathbf{O}): \mathrm{Y}=69.93-0.288 \mathrm{x}, \mathrm{r}^{2}=0.8547$, fruiting uprights $(\mathrm{O}): \mathrm{Y}=79.39-0.274 \mathrm{x}, \mathrm{r}^{2}=$ 0.7010. (F) CN ratio at preharvest, vegetative uprights $(\bullet): \mathrm{Y}=70.87-0.222 \mathrm{x}, \mathrm{r}^{2}=0.7156$, fruiting uprights $(\bigcirc): \mathrm{Y}=82.95-0.296, \mathrm{r}^{2}=0.8025$.

cranberry tissue may be insufficient for other reasons. Therefore, we hypothesize that $\mathrm{N}$ affects $\mathrm{CHO}$ and therefore fruit production in an indirect manner.

Understanding the roles of $\mathrm{N}$ and $\mathrm{CHO}$ in vine and fruit growth is essential to increasing yield of cranberry. To our knowledge, there have been no previous reports on the effects of $\mathrm{N}$ fertilization on $\mathrm{CHO}$ in cranberry tissues. The objective of these studies was to determine the effect of $\mathrm{N}$ on carbon production and partitioning in cranberry.

\section{Methods and Materials}

\section{Expt. 1}

Experimental design. The study was established on healthy 'Stevens' cranberry vines growing at State Bog (University of Massachusetts Amherst Cranberry Station, E. Wareham, Mass., lat. $41^{\circ} 45^{\prime} \mathrm{N}$, long. $70^{\circ} 40^{\circ} \mathrm{W}$ ) in a randomized complete block design with four replications. Plot size was $1 \mathrm{~m} \times 1 \mathrm{~m}$ with $1 \mathrm{~m}$ of guard vines between plots. $\mathrm{N}$ treatments of $0,22,45,67$, and 90 $\mathrm{kg} \cdot \mathrm{ha}^{-1}(21 \mathrm{~N}-0 \mathrm{P}-0 \mathrm{~K})$ were applied in a $30 \%$

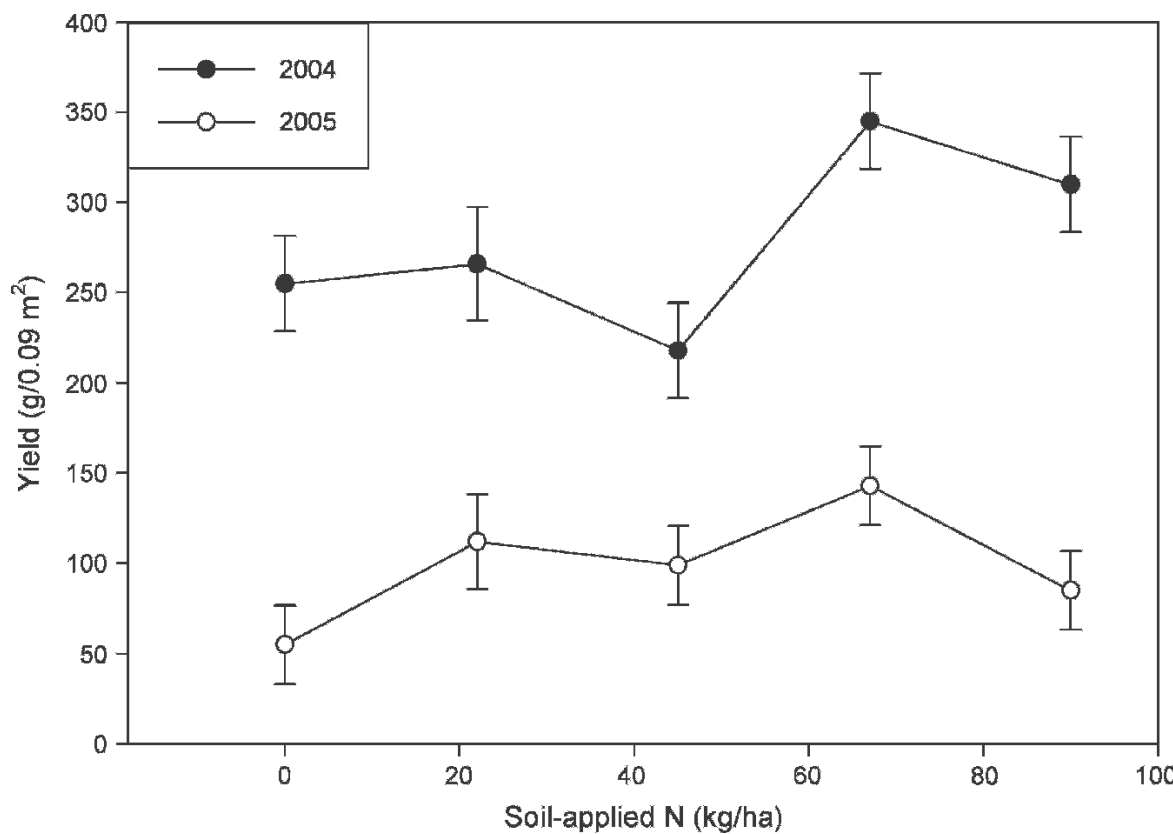

Fig. 3. The effect soil-applied $\mathrm{N}$ on yield in 2004 ( ) and 2005 (○) of Stevens cranberry. Yield was reduced in 2005 as a result of pest damage. 

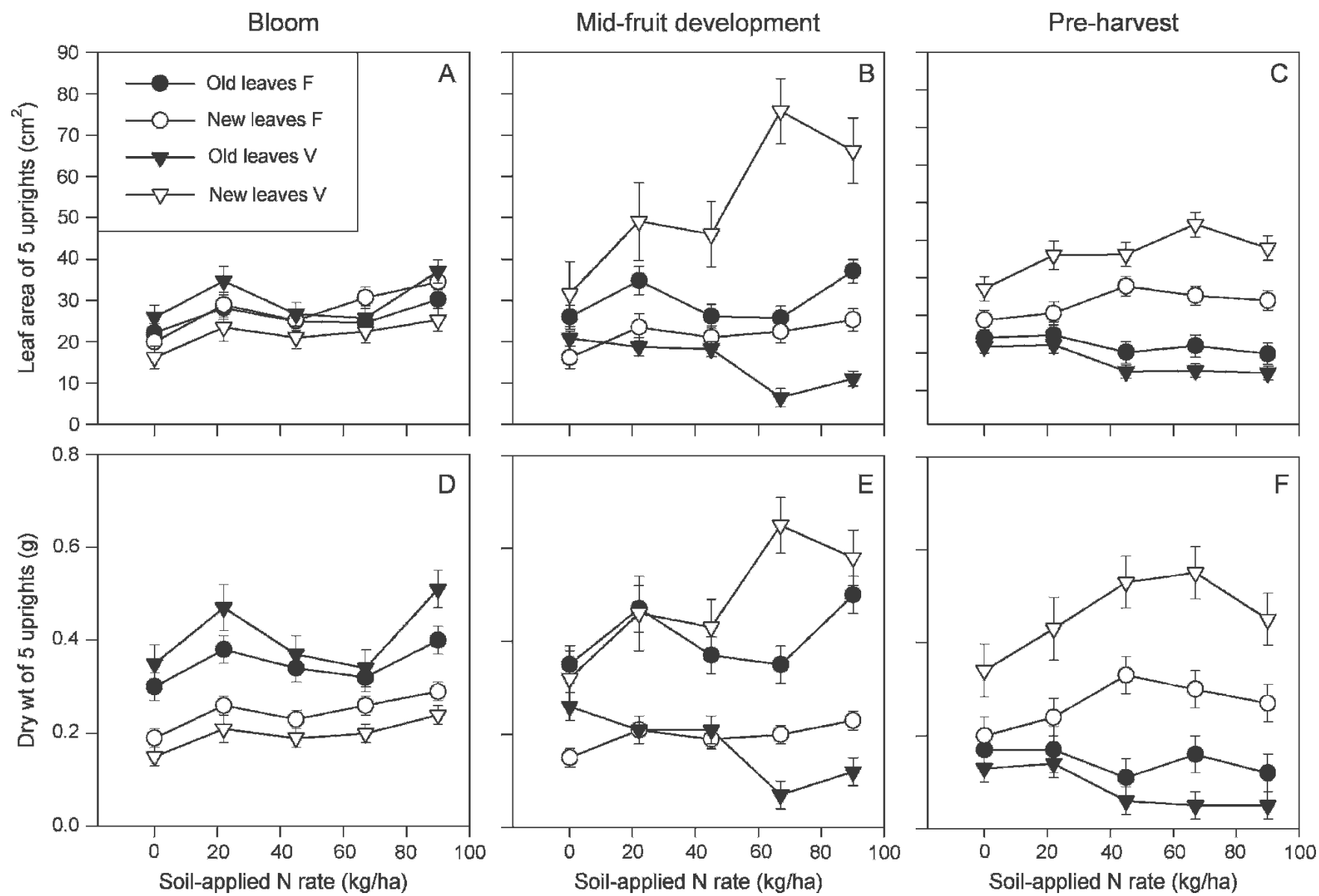

Fig. 4. The effect of soil-applied $N$ application on leaf area of five vegetative and five fruiting uprights at (A) bloom, (B) midfruit development, (C) preharvest, and on dry weight of the same five uprights at (D) bloom, (E) midfruit development, and (F) preharvest of Stevens in 2005.

to 30 to $35 \%$ split-application at roughneck (24 May 2004, 6 June 2005), 75\% bloom (25 June 2004, 5 July 2005), and 2 to 3 weeks after bloom (15 July 2004, 25 July 2005). $\mathrm{P}(0 \mathrm{~N}-20 \mathrm{P}-0 \mathrm{~K})$ was applied at a rate of $22 \mathrm{~kg} \cdot \mathrm{ha}^{-1}$ and $\mathrm{K}(0 \mathrm{~N}-0 \mathrm{P}-41 \mathrm{~K})$ at a rate of $44 \mathrm{~kg} \cdot \mathrm{ha}^{-1}$. Aside from fertilization, standard management practices were followed for MA cranberry bogs.

Leaf analysis. Five vegetative and five fruiting uprights were collected from each plot at bloom (27 June), midfruit development (9 Aug.), and preharvest (28 Sept.) in 2005. Leaves were separated from the stem and divided into old (i.e., previous season) and new (i.e., current season) leaves in each upright sample. Leaf area of old and new leaves in each sample was quantified using a leaf area meter (Li-3000; LI-COR, Lincoln, $\mathrm{Neb}$.). Leaves were then oven-dried for $5 \mathrm{~d}$ at $80{ }^{\circ} \mathrm{C}$ and dry weight was measured using an OHaus Explorer balance (OHaus, Pine Brook, N.J.) sensitive to $\pm 1 \mathrm{mg}$.

Chlorophyll determination. Samples were collected for chlorophyll analysis at preharvest in 2004 (15 Sept.) and at bloom (27 June), midfruit development (9 Aug.), and preharvest (28 Sept.) in 2005. At each sampling date, five vegetative and five fruiting uprights were collected from each plot. In 2004, two subsamples of $100 \mathrm{mg}$ each were randomly removed from each sample of five uprights. In 2005, old and new growth was separated on each group of uprights, and two subsamples of $100 \mathrm{mg}$ each were removed so that old growth from vegetative uprights, new growth from vegetative uprights, old growth from fruiting uprights, and new growth from fruiting uprights were analyzed separately.

Subsamples were incubated in $7 \mathrm{~mL}$ of dimethyl sulfoxide (DMSO) (Fisher Scientific, Pittsburgh, Pa.) at $65{ }^{\circ} \mathrm{C}$ for 6 hours. Samples were then placed in a refrigerator overnight at $4{ }^{\circ} \mathrm{C}$. In the morning, the samples were brought up to $22{ }^{\circ} \mathrm{C}$ and the volume adjusted with DMSO to $10 \mathrm{~mL}$. Absorbances were read at 645 and $663 \mathrm{~nm}$ using a Hitachi U-1100 spectrophotometer (Hitachi Ltd., Tokyo, Japan). Chlorophyll concentration was calculated using the following equations:

$$
\begin{gathered}
\text { Chl A }(\mathrm{mg} / \mathrm{g} \text { frwt. })=\left[\left(12.7\left(\mathrm{~A}_{663}\right)\right.\right. \\
\left.-2.69\left(\mathrm{~A}_{645}\right)\right] \times(\mathrm{V} / 1000 \times \mathrm{W})
\end{gathered}
$$

$$
\begin{gathered}
\text { Chl B }(\mathrm{mg} / \mathrm{g} \text { frwt. })=\left[\left(22.9\left(\mathrm{~A}_{645}\right)\right.\right. \\
\left.-4.68\left(\mathrm{~A}_{663}\right)\right] \times(\mathrm{V} / 1000 \times \mathrm{W})
\end{gathered}
$$

Chl AB (mg/g frwt. $)=\left[\left(20.2\left(\mathrm{~A}_{645}\right)\right.\right.$

$$
\left.+8.02\left(\mathrm{~A}_{663}\right)\right] \times(\mathrm{V} / 1000 \times \mathrm{W})
$$

where A represents the absorbance reading of the chlorophyll extract at the specific indicated wavelength, $\mathrm{V}$ is the final volume of the solution, and $\mathrm{W}$ is the actual fresh weight in $\mathrm{g}$ of the tissue extracted.

Carbohydrate and nitrogen analysis. At midfruit development (3 Aug.) and preharvest (15 Sept.) in 2004 and at bloom (27 June) midfruit development (9 Aug.), and preharvest (28 Sept.) in 2005, 20 whole vegetative, and 20 whole fruiting uprights were removed from each plot during midmorning. In addition, root samples were taken from the middle section of the plots in replications three and four at the preharvest sampling in 2005 using an auger. Roots were carefully washed. Uprights and roots were oven-dried at $80{ }^{\circ} \mathrm{C}$ for a minimum of $5 \mathrm{~d}$, ground to 40 mesh, and carbohydrate concentration was analyzed according to the protocol described by Botelho and Vanden Heuvel (2005). Total tissue carbon $(\mathrm{C})$ and nitrogen $(\mathrm{N})$ were analyzed by dry combustion according to the methods of Nelson and Sommers (1996) and Bremner (1996) on a LECO CNS analyzer (St. Joseph, Mich.) and expressed as a percentage of dry weight.

Yield analysis. Fruit were collected from the middle $0.093-\mathrm{m}^{2}$ area of the plot before commercial harvest. Total fruit weight and number were recorded. Average fruit size was calculated by dividing total fruit weight by total fruit number. In 2005, significant damage to the fruit occurred as a result of an infestation of cranberry fruitworm. 
Mid-fruit development
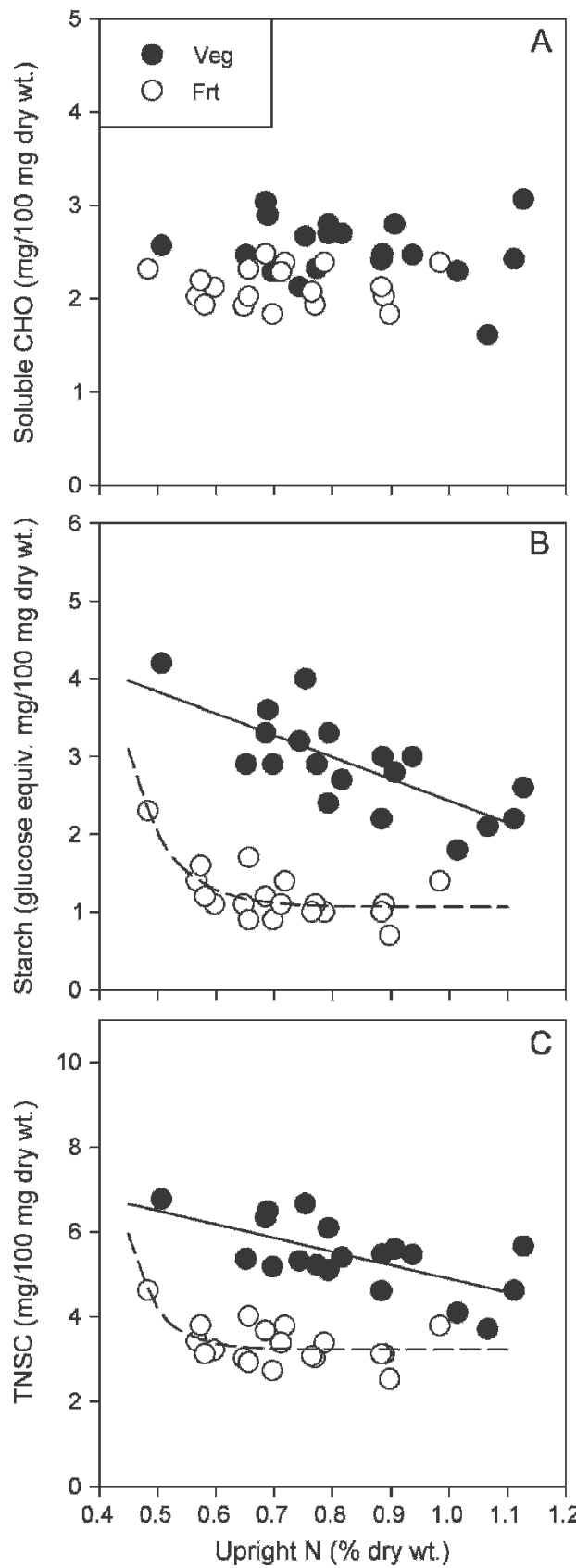

C

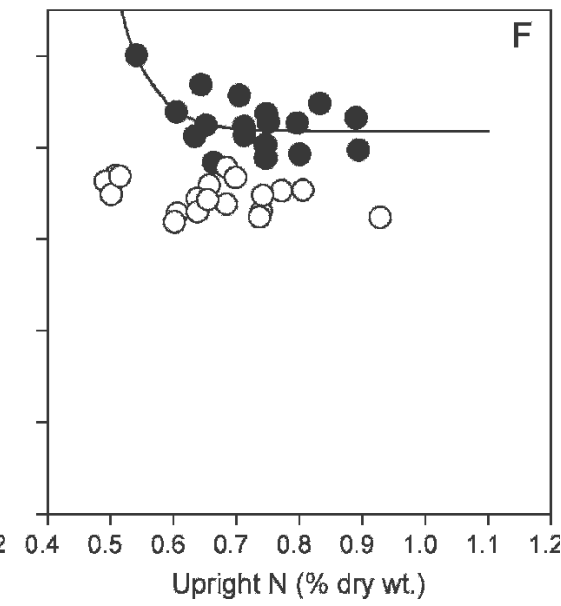

Fig. 5. The effect of upright N concentration on Stevens uprights in 2004. (A) Soluble carbohydrates, vegetative uprights $(-)$ and fruiting uprights $(O): \mathrm{r}^{2}<0.20$ at midfruit development. (B) Starch, vegetative uprights $(\bullet): \mathrm{Y}=5.24-2.81 \mathrm{x}, \mathrm{r}^{2}=0.5527$, fruiting uprights $(\mathrm{O}): \mathrm{Y}=1.07+1738 \mathrm{e}^{-15.00 \mathrm{x}}, \mathrm{r}^{2}=$ 0.6223 at midfruit development. (C) Total nonstructural carbohydrates, vegetative uprights $(\bullet)$ : $\mathrm{Y}=$ $8.11-3.22 \mathrm{x}, \mathrm{r}^{2}=0.4223$, fruiting uprights $(\mathrm{O}): \mathrm{Y}=3.23+24,442 \mathrm{e}^{-20.23 \mathrm{x}}, \mathrm{r}^{2}=0.4032$ at midfruit development. (D) Soluble carbohydrates, vegetative uprights $(\bullet)$ and fruiting uprights $(O): \mathrm{r}^{2}<0.20$ at preharvest. (E) Starch, vegetative uprights, $(\bullet)$ : $\mathrm{Y}=4.26+708 \mathrm{e}^{-11.33 \mathrm{x}}, \mathrm{r}^{2}=0.4365$, fruiting uprights (O): $\mathrm{Y}=4.37-1.49 \mathrm{x}, \mathrm{r}^{2}=0.2898$ at preharvest. $(\mathbf{F})$ Total nonstructural carbohydrates, vegetative uprights $(\bullet): \mathrm{Y}=8.36+259,514 \mathrm{e}^{-22.09 x}, \mathrm{r}^{2}=0.4200$, fruiting uprights $(\mathrm{O}): \mathrm{r}^{2}<0.20$ at preharvest.

Data analysis. Regression analyses for the relationship between soil-applied $\mathrm{N}$ and tissue $\mathrm{N}$ and for the relationship between tissue $\mathrm{N}$ and carbohydrate concentration were performed using Proc GLM in SAS (SAS Institute, Cary, N.C.). If a linear relationship was not a good fit for the data (as evidenced by the $r^{2}$ ), an asymptotic relationship was tested using Proc NLIN in the form of

$$
\mathrm{Y}=\mathrm{a}+\mathrm{b} \mathrm{e}^{-\mathrm{cx}}
$$

where $\mathrm{a}=$ asymptote, $\mathrm{b}=$ intercept, $\mathrm{c}=$ rate of approach to asymptote, and $\mathrm{x}=$ the $\mathrm{x}$ axis value. The $r^{2}$ for the nonlinear curves were approximated by dividing model sum of squares by the corrected total sum of squares (Steel et al., 1997).

\section{Expt. 2}

Plant material. Actively growing 'Stevens' cranberry uprights were collected from the University of Massachusetts Amherst
Cranberry Experiment Station research bog (State Bog), E. Wareham, Mass. (lat.: 41 ${ }^{\circ} 45^{\prime}$ $\mathrm{N}$, long.: $70^{\circ} 40^{\prime}$ W) in May 2004. Four nonrooted cuttings, $10 \mathrm{~cm}$ in length, were planted in a $10-\mathrm{cm}$ pot containing $90: 10(\mathrm{v}: \mathrm{v})$ of sand (collected from State Bog) and 'Berger' peatmoss (R.F. Morse, Wareham, Mass.). Pots were irrigated daily using overhead mist. Osmocote ${ }^{\circledR}$ slow-release fertilizer $(14 \mathrm{~N}-6 \mathrm{P}-11 \mathrm{~K})$ was applied to the surface of the soil mix 4 weeks after planting. Vines were stored in the dark over the winter at 3 $( \pm 1)^{\circ} \mathrm{C}$ for a period of 16 weeks to induce dormancy. In March 2005, they were placed in a greenhouse under ambient temperature and light conditions $\left(>1000 \mu \mathrm{mol} \cdot \mathrm{m}^{-2} \cdot \mathrm{s}^{-1} \mathrm{PPF}\right.$ in full sun conditions).

Five trays of potted vines ( 1 tray $=15$ pots of uprights) were fertilized on a per-pot basis according to the treatments, schedule and quantities in Expt. 1. Vines were then rerandomized and allowed to grow in the greenhouse.

Because few uprights produced fruit as a result of lack of pollinators in the greenhouse, pots containing fruiting uprights were removed from the experiment. Four pots containing all vegetative uprights of each soil $\mathrm{N}$ treatment (20 pots total) were then randomly selected from the remaining experimental units for analysis of NCER from 13 July through 15 July. NCER of six uprights per pot was measured using a CIRAS-2 portable infrared gas analyzer connected to an automated PLC5(C) conifer cuvette (PP Systems, Amesbury, Mass.). The chamber temperature was maintained at $25( \pm 2){ }^{\circ} \mathrm{C}$ during measurement. Air flow through the cuvette was 400 $\mathrm{mL} \cdot \mathrm{min}^{-1}$ with $\mathrm{CO}_{2}$ maintained at $380 \pm 10$ ppm. The chamber was clamped around the top $10 \mathrm{~cm}$ of the upright for $3 \mathrm{~min}$, then measurements of NCER were taken every $15 \mathrm{~s}$ until a steady rate $\left( \pm 0.2 \mu \mathrm{mol} \cdot \mathrm{m}^{-2} \cdot \mathrm{s}^{-1}\right)$ was reached $(\approx 1 \mathrm{~min})$. Approximately 700 $\mu \mathrm{mol} \cdot \mathrm{m}^{-2} \cdot \mathrm{s}^{-1} P P F$ was supplied to the vines during measurement using a HPS light source. Measurements were made between 1030 and 1400 EST. After measurement, the tissue in the chamber was removed from the remainder of the vine. As the measured tissue had to be combined to provide enough mass for $\mathrm{N}$ quantification (performed as described in Expt. 1), NCER was averaged for the six uprights measured per pot.

Data analysis. Nitrogen response data were fit to the model:

$$
\mathrm{Y}=\mathrm{a}-\mathrm{b} \mathrm{e}^{-\mathrm{cx}}
$$

where $\mathrm{a}=$ asymptote, $\mathrm{b}=$ intercept, $\mathrm{c}=$ rate of approach to asymptote, and $\mathrm{x}=$ the $\mathrm{x}$-axis value. The $r^{2}$ for the response curves were approximated by dividing model sum of squares by the corrected total sum of squares (Steel et al., 1997).

\section{Results and Discussion}

Expt. 1. Increasing the soil fertilizer $\mathrm{N}$ rate resulted in a linear increase in tissue $\mathrm{N}$ 
Bloom
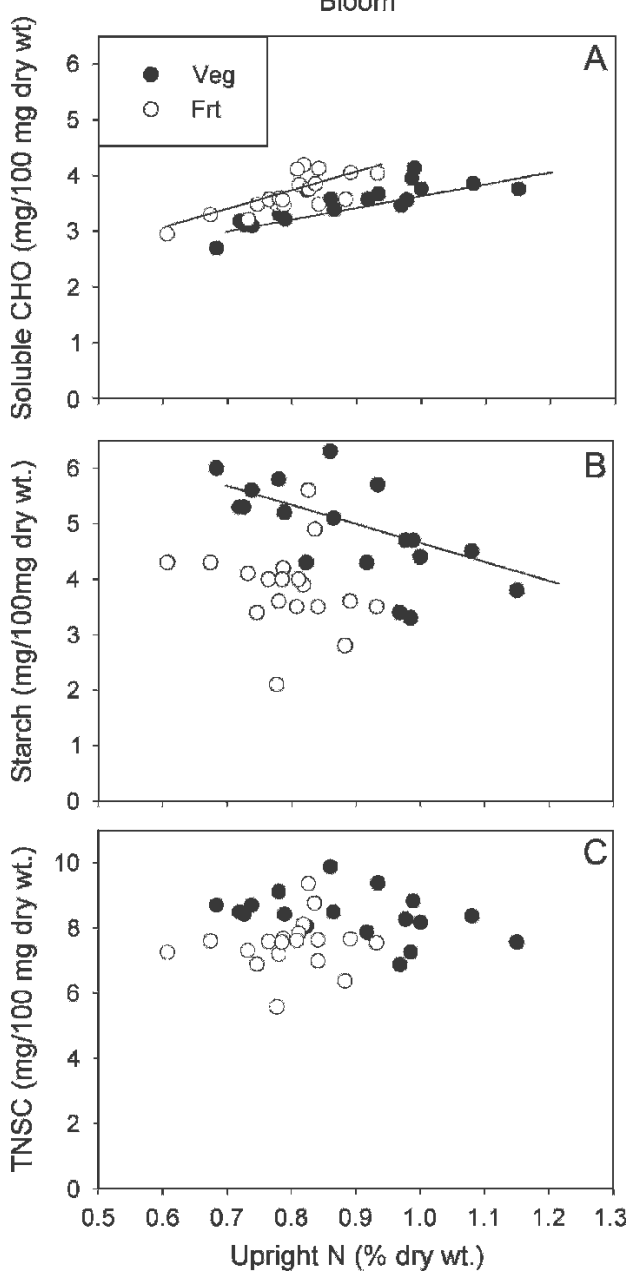

Mid-fruit development
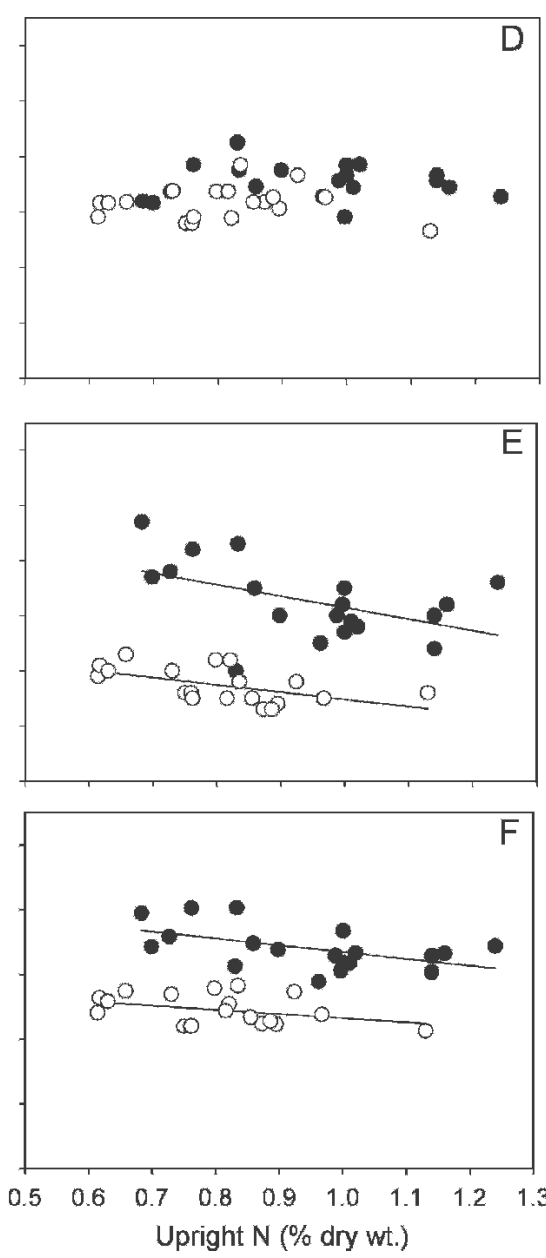

Preharvest
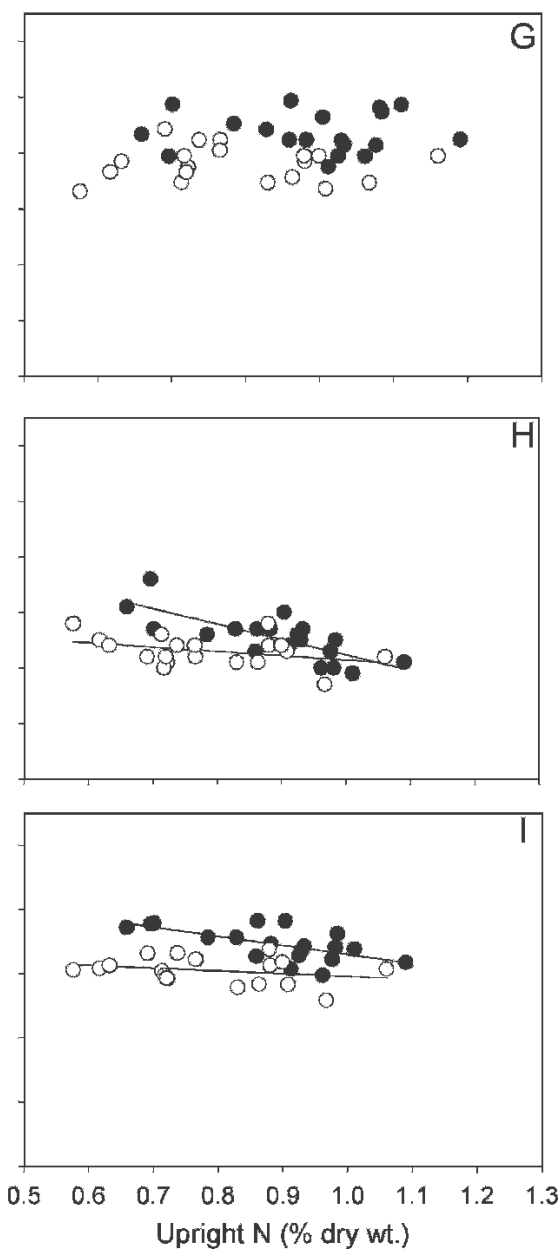

Fig. 6. The effect of upright $\mathrm{N}$ concentration on Stevens uprights in 2005. (A) Soluble carbohydrates, vegetative uprights $(\bullet): Y=1.60+2.15 \mathrm{x}, \mathrm{r}^{2}=0.7548$, fruiting uprights $(\mathrm{O}): \mathrm{Y}=0.91+3.46 \mathrm{x}, \mathrm{r}^{2}=0.5822$ at bloom. (B) Starch, vegetative uprights $(\mathbf{O}): \mathrm{Y}=7.97-3.44 \mathrm{x}, \mathrm{r}^{2}=0.4176$, fruiting uprights $(\mathrm{O}): \mathrm{r}^{2}<0.20$ at bloom. (C) Total nonstructural carbohydrates, vegetative uprights $(-)$ and fruiting uprights $(\bigcirc)$ : $\mathrm{r}^{2}<0.20$ at bloom. (D) Soluble carbohydrates, vegetative uprights $(\bullet)$ and fruiting uprights $(\bigcirc): \mathrm{r}^{2}<0.20$ at midfruit development. (E) Starch, vegetative uprights $(\bullet): \mathrm{r}^{2}<0.20$, fruiting uprights $(\bigcirc)$ : $\mathrm{Y}=2.81-$ $1.32 \mathrm{x}, \mathrm{r}^{2}=0.2915$ at midfruit development. (F) Total nonstructural carbohydrates, vegetative uprights $(\mathbf{O})$ : $\mathrm{Y}=8.78-2.10 \mathrm{x}, \mathrm{r}^{2}=0.2711$, fruiting uprights $(\bigcirc): r^{2}<0.20$ at midfruit development. (G) Soluble carbohydrates, vegetative uprights $(\bullet)$ and fruiting uprights $(\bigcirc): r^{2}<0.20$ at preharvest. $(\mathbf{H})$ Starch, vegetative uprights $(\bullet)$ : $\mathrm{Y}=5.01-2.77 \mathrm{x}, \mathrm{r}^{2}=0.5762$, fruiting uprights $(\mathrm{O}): \mathrm{r}^{2}<0.20$ at preharvest. (I) Total nonstructural carbohydrates, vegetative uprights $(\bullet): \mathrm{Y}=9.44-2.84 \mathrm{x}, \mathrm{r}^{2}=0.3944$, fruiting uprights $(O): \mathrm{r}^{2}<0.20$ at preharvest.

regardless of date of collection (Figs. 1 and 2 ). Such a response is consistent with previous studies on response of cranberry to $\mathrm{N}$ (Davenport and Provost, 1994; Davenport and Vorsa, 1999; DeMoranville, 1992). The overall decline in tissue $\mathrm{N}$ concentration during the season is also consistent with previous findings (DeMoranville, 1992). Current recommendations for upright tissue sampling to monitor $\mathrm{N}$ status of the vine are to collect tissue between $15 \mathrm{Aug}$. and $15 \mathrm{Sept}$. when tissue nutrient levels have stabilized (Davenport et al., 1995) with $0.90 \%$ to $1.10 \%$ $\mathrm{N}$ as the established adequate $\mathrm{N}$ range. Although we chose our $\mathrm{N}$ application rates according to grower practices, and with the objective of obtaining uprights with that were much higher and lower than recommended $\mathrm{N}$ concentrations, very few uprights achieved the recommended concentration of $\mathrm{N}$ in 2004 , and the majority of these were vegetative uprights at the highest $\mathrm{N}$ rate (Fig. 1). The portion of the bed where this experiment was established had not been previously sampled for $\mathrm{N}$ concentration, but the vines looked healthy and similar to those found on other commercial beds in MA. By preharvest, tissue $\mathrm{N}$ concentrations for all but one sample were below the normal range in the first year of the study (Fig. 1). Plots treated with the highest rate of $\mathrm{N}$ application did not demonstrate excessive runner production.

Overall tissue $\mathrm{N}$ concentration was higher in the second year (Fig. 2) compared with the first year of study (Fig. 1). The low N concentration in 2004 may have been the result of increased fruit production in that year compared with both 2003 (average marketable yield $193 \mathrm{~g} / 0.093 \mathrm{~m}^{2}$ in nearby plots) and 2005 (Fig. 3), resulting in greater N partitioning to fruit rather than to vegetative growth (Davenport and Vorsa, 1999). Like in 2004, tissue $\mathrm{N}$ concentration in 2005 was greater in vegetative uprights than in fruiting uprights (Fig. 2). This is in contrast to the findings of Hagidimitriou (1993) in which there was little to no difference in tissue $\mathrm{N}$ concentration of vegetative and fruiting uprights grown in Wisc. However, recent reports indicate that cranberry tissue $\mathrm{N}$ concentration in Wisconsin Stevens is higher than many other growing regions (T.R. Roper, personal communication), which suggests that the differences between fruiting and vegetative tissue $\mathrm{N}$ concentration noted in this study may occur when $\mathrm{N}$ tissue concentrations are low or below adequate. Nitrogen and $\mathrm{CHO}$ concentrations may have been even lower if sampling had occurred at fruit set when resources are most limiting (Roper et al., 1992).

Roper and Klueh (1996) determined that current year leaves on fruiting uprights (not vegetative uprights) were the source of $\mathrm{C}$ for fruit production. In our study, regardless of sampling date, fruiting uprights had greater $\mathrm{C}: \mathrm{N}$ ratios compared with vegetative uprights (Figs. 1 C, D and 2 D-F). C:N ratio decreased with increasing $\mathrm{N}$ rate regardless of tissue 


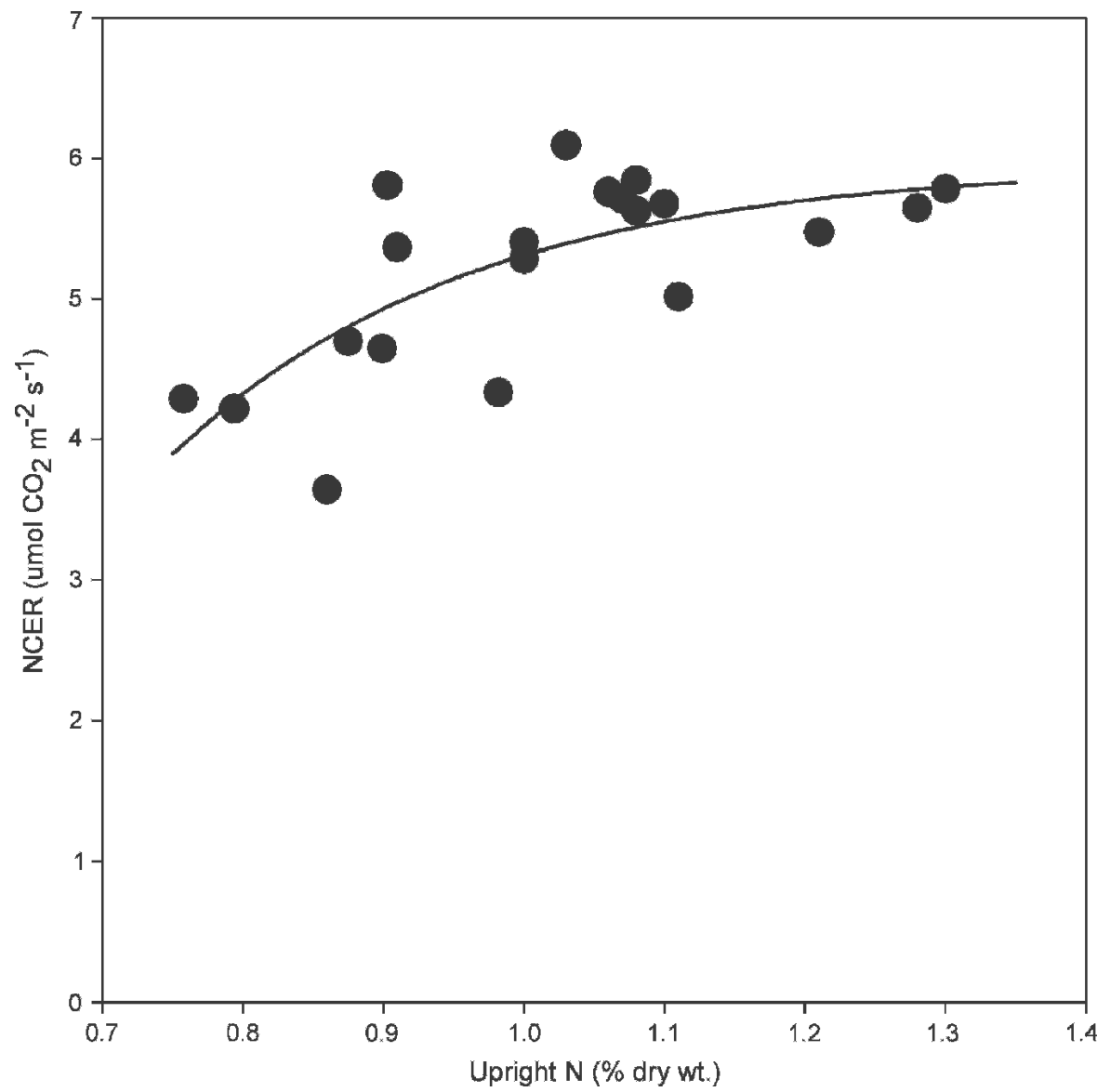

Fig. 7. The effect of upright $N$ concentration on net carbon exchange rate $Y=5.96-66.69 e^{-4.638 x}, r^{2}=$ 0.5171 of potted Stevens vegetative uprights at midfruit development.

type or time of collection. However, tissue C concentration showed little to no relationship with tissue $\mathrm{N}$ concentration regardless of whether the upright was fruiting or vegetative (data not shown). Tissue $\mathrm{N}$ concentration occurred within or above the adequate range for vegetative uprights fertilized at above the $22 \mathrm{~kg} \cdot \mathrm{ha}^{-1}$ rate during midfruit development and preharvest (Fig. 2). However, fruiting uprights attained an optimal range of $\mathrm{N}$ concentration only at the highest soil-applied $\mathrm{N}$ rate, further supporting the hypothesis that berry production may lead to a drain on fruiting upright $\mathrm{N}$.

At bloom, leaf area of old (i.e., previous season) and new (i.e., current season) leaves on vegetative and fruiting uprights were similar (Fig. 4A), although dry weights of old leaves were greater than new leaves (Fig. 4D). Soil-applied $\mathrm{N}$ had little effect on leaf area and dry weight of leaves early in the season (Fig. 4A, D). At midfruit development, leaf area and dry weight of new leaves on vegetative uprights increased with the two greatest levels of soil-applied N (67 and $90 \mathrm{~kg} \cdot \mathrm{ha}^{-1}$ ) (Fig. 4B, E) with a concomitant decrease in these variables in the old leaves of vegetative uprights. This suggests that either increased $\mathrm{N}$ application or increased development of new leaves caused older leaves to abscise from vegetative uprights. At midfruit development, leaf area of older leaves of fruiting uprights was greater than that of new leaves (Fig. 4B). By harvest, leaf area and weight of new leaves was greater than that of old leaves regardless of whether the uprights were fruiting or vegetative (Fig. 4C, F) but vegetative uprights had greater leaf area and leaf dry weight compared with fruiting tissue, suggesting that developing fruits on the fruiting uprights depleted resources from the leaves.

Compared with midfruit development, there was little effect of soil-applied $\mathrm{N}$ on leaf area at preharvest (Fig. 4C). However, tissue dry weight increased with increasing $\mathrm{N}$ in new fruiting and vegetative leaves up to the $44 \mathrm{~kg} \cdot \mathrm{ha}^{-1}$ and $67 \mathrm{~kg} \cdot \mathrm{ha}^{-1} \mathrm{~N}$ rates, respectively, whereas old leaf tissue $\mathrm{N}$ decreased slightly in vegetative leaves above $22 \mathrm{~kg} \cdot \mathrm{ha}^{-1}$ N. Dry weight of old leaves on fruiting uprights was not N-responsive (Fig. 4F). The increase in both leaf area and dry matter in favor of new leaf tissue between the midbloom and harvest sampling times suggests that leaf functionality declines with age. This observation is further supported by the negative or nonresponsiveness of the old tissue to soil-applied $\mathrm{N}$, whereas new leaf tissue showed some positive response (Fig. 4). Although increased soil-applied $\mathrm{N}$ had little effect on leaf area per upright at this time (Fig. 4C), it did improve leaf dry weight in new leaves of both types of uprights (Fig.
4F), suggesting an enhancement of photosynthetic capacity in these leaves.

Increased $\mathrm{N}$ per upright was associated with a linear increase in chlorophyll A (ChlA), chlorophyll B (ChlB), and total chlorophyll (ChlAB) in both types of uprights in both years of the study (data not shown). Chlorophyll concentration did not differ between old and new leaves in 2005. At prebloom and midfruit development, ChlA, $\mathrm{ChlB}$, and ChlAB was similar in fruiting and vegetative uprights, although preharvest, ChlAB concentration was greater in fruiting uprights in both years of the study with ChlAB of fruiting uprights ranging from $\approx 0.7$ to $1.1 \mathrm{mg} / \mathrm{g}$ leaves (frwt.) and from $\approx 0.5$ to $0.9 \mathrm{mg} / \mathrm{g}$ leaves (frwt.) in vegetative uprights (data not shown) in 2005. Chlorophyll concentrations were consistent with the range reported for field-grown 'Stevens' in Wisc. by Hagidimitriou (1993).

In the first year of the study, leaf $\mathrm{N}$ was negatively related to starch concentration in vegetative uprights (Fig. 5B); however, starch concentration of fruiting uprights declined only at low $\mathrm{N}$ concentrations and then stabilized (Fig. 5B). Such phenomenon could be the result of midmorning sampling, because previous studies suggested that carbon export may have been higher in leaves with greater $\mathrm{N}$ during the night (Chen and Cheng, 2003). Fruiting uprights contained significantly less starch than vegetative uprights (Fig. 5B), and TNSC declined with increased upright $\mathrm{N}$ concentration (Fig. 5C). By preharvest, starch concentration was still negatively affected by increased $\mathrm{N}$ concentration (Fig. 5E). This decrease in starch concentration did not affect TNSC of fruiting uprights (Fig. 5F).

Starch concentration not only decreased with increased $\mathrm{N}$ in uprights, but also declined in roots at preharvest. Although we only collected roots from two replicates of the field experiment, a strong negative relationship was discernible between soil-applied $\mathrm{N}$ and root starch as well as $\mathrm{N}$ application rate and root TNSC (data not shown).

The effect of $\mathrm{N}$ on $\mathrm{CHO}$ was similar in the second year compared with the first. In the second year of the study, soluble carbohydrates at bloom in both upright types were positively (but not strongly) related to increased $\mathrm{N}$ concentration (Fig. 6A). Starch concentration of vegetative uprights was negatively related to $\mathrm{N}$ (Fig. 6B), whereas TNSC remained unaffected by upright $\mathrm{N}$ concentration (Fig. 6C). During both midfruit development and preharvest sampling periods, soluble carbohydrates were unaffected by upright $\mathrm{N}$ (Fig. 6D, G), but both starch (Fig. 6E, H) and TNSC (Fig. 6F, I) tended to decline in fruiting and vegetative uprights with increased N. However, by preharvest, there was no difference between fruiting and vegetative upright starch and TNSC at high tissue $\mathrm{N}$ concentrations $(>0.09 \%)$ (Fig. $6 \mathrm{H}$, I). As root-soluble carbohydrates, starch, and hence TNSC concentrations tend to increase during the fall (Botelho and Vanden Heuvel, 
2006), and little $\mathrm{C}$ moves from vegetative uprights to fruiting uprights (Roper and Klueh, 1996), it is possible that excess carbohydrates in vegetative uprights are moved into the roots later in the season to prepare for dormancy.

Because increased upright $\mathrm{N}$ did not improve soluble carbohydrates, starch, or TNSC at midfruit development, the surge in leaf area and dry weight increase that occurred at that growth stage (Fig. 4) may be the result of increased $\mathrm{N}$ uptake. There was a surge in leaf area and dry weight accumulation in vegetative uprights, but not in fruiting uprights, which had lower $\mathrm{N}$ and lower $\mathrm{CHO}$ concentrations. These results lead us to hypothesize that current season vegetative growth may limited by $\mathrm{N}$.

It is possible that uprights in higher $\mathrm{N}$ treatments had, on average, lower light interception by leaves as a result of interleaf shading as a result of greater vegetative growth (Fig. 4), possibly resulting in lower NCER of uprights and hence lower carbohydrate concentrations.

Expt. 2. NCER was increased in vegetative uprights with increased $\mathrm{N}$ concentration (Fig. 7) likely as a result of slightly increased stomatal conductance (data not shown), similar to the results noted by Chen and Cheng (2003) in Concord grapevines (Vitis labruscana Bailey). The low NCER noted in leaves with low $\mathrm{N}$ is likely a factor of reduced activity of key enzymes involved in carbon assimilation (Chen and Cheng, 2003).

\section{Conclusions}

Tissue $\mathrm{N}$ concentration increased with increasing $\mathrm{N}$ fertilizer application. In the first year of the study, upright tissue $\mathrm{N}$ concentration was below the recommended concentration in almost all samples. Tissue $\mathrm{N}$ concentration was greater in the second year, when there was little to no fruit resulting from adverse insect pressures. This, coupled with the findings of higher $\mathrm{N}$ concentration in vegetative uprights than in fruiting uprights, suggests that $\mathrm{N}$ partitioning to the fruit is largely derived from the uprights they are borne on.

Increased upright $\mathrm{N}$ concentration was associated with increases in chlorophyll (A, $\mathrm{B}$, and total) concentration regardless of whether the tissue was or was not fruit- bearing. Starch concentration and TNSC were negatively related to tissue $\mathrm{N}$ content at bloom, fruit development, and preharvest growth stages, more so in vegetative uprights than fruiting uprights. This decrease in TNSC was not attributable to a negative effect of $\mathrm{N}$ on NCER. Increased N was also associated with gains in leaf tissue dry matter and leaf area. These results suggest that current season growth in vegetative uprights is controlled more by $\mathrm{N}$ than $\mathrm{CHO}$, whereas the results for fruiting uprights do not clearly suggest either $\mathrm{N}$ or $\mathrm{CHO}$ in this role. This study suggests that by maintaining an adequate $\mathrm{N}$ supply, vegetative uprights in a given year will develop the leaf tissue required to sustain fruit production in the successive year, assuring the continuity of berry production.

\section{Literature Cited}

Baumann, T.E. and G.W. Eaton. 1986. Competition among berries on the cranberry upright. J. Amer. Soc. Hort. Sci. 111:869-872.

Birrenkott, B.A., C.A. Henson, and E.J. Stang. 1991. Carbohydrate levels and the development of fruit in cranberry. J. Amer. Soc. Hort Sci. 116:174-178

Birrenkott, B.A. and E.J. Stang. 1990. Selective flower removal increases cranberry fruit set. HortScience 25:1226-1228.

Botelho, M.R. and J.E. Vanden Heuvel. 2005. High dissolved oxygen concentration of floodwater reduces carbohydrate concentration of cranberry uprights during flooding. HortScience 40:569573.

Botelho, M.R. and J.E. Vanden Heuvel. 2006. Preliminary assessment of the impact of current flooding practices on non-structural carbohydrate concentrations of cranberry. HortTechnology 16:277-285.

Bremner, J.M. 1996. Nitrogen-total, p. 10851122. In: J.M. Bartles (Ed.). Methods of Soil Analysis Part 3-Chemical Methods. Book 5 in the SSSA book Series ASA/CSSA/SSSA Press, Madison, Wisc.

Chen, L. and L. Cheng. 2003. Carbon assimilation and carbohydrate metabolism of 'Concord' grape leaves in response to nitrogen supply. J. Amer. Soc. Hort. Sci. 128:754-760.

Cheng, L. and L.H. Fuchigami. 2002. Growth of young apple trees in relation to reserve nitrogen and carbohydrates. Tree Physiol. 22:1297-1303.

Cheng, L., G. Xia, and T. Bates. 2004. Growth and fruiting of young 'Concord' grapevines in relation to reserve nitrogen and carbohydrates. J. Amer. Soc. Hort. Sci. 129:660-666.

Davenport, J., C. DeMoranville, J. Hart, K. Patten, L. Petersen, T. Planer, A. Poole, T. Roper, and
J. Smith. 1995. Cranberry tissue testing for producing beds in North America. Jointly published by Northland Cranberries, Ocean Spray Cranberries, Inc., Oregon State University, University of Massachusetts Cranberry Experiment Station, University of Wisconsin, and Washington State University Bulletin.

Davenport, J., C. DeMoranville, J. Hart, and T. Roper. 2000. Nitrogen for bearing cranberries in North America. OSU, UMASS, WSU and UW Extension Bulletin EM 8741.

Davenport, J.R. and J. Provost. 1994. Cranberry tissue nutrient levels as impacted by three levels of nitrogen fertilizer and their relationship to fruit yield and quality. J. Plant Nutr. $17: 1625-1634$

Davenport, J.R. and N. Vorsa. 1999. Cultivar fruiting and vegetative response to nitrogen fertilizer in cranberry. J. Amer. Soc. Hort. Sci. 124:90-93.

DeMoranville, C.J. 1992. Cranberry nutrients, phenology, and N-P-K fertilization. PhD Diss. Univ. of Mass. Amherst

Hagidimitriou, M. 1993. Carbohydrate partitioning and photosynthesis in cranberry (Vaccinium macrocarpon Ait.) PhD Diss. Univ. of Wisconsin, Madison.

Hagidimitriou, M. and T.R. Roper. 1994. Seasonal changes in nonstructural carbohydrates in cranberry. J. Amer. Soc. Hort. Sci. 119:1029-1033.

Hart, J.M., A. Poole, K.L. Wilder, and B.C. Strik 1990. Nitrogen rate and timing affect on cranberry yield and yield components. HortScience 25:1148.

Nelson, D.W. and L.E. Sommers. 1996. Total carbon, organic carbon and organic matter, $p$ 961-1010. In: J.M. Bartles (Ed.). Methods of Soil Analysis Part 3-Chemical Methods. Book 5 in the SSSA Book Series ASA/CSSA/ SSSA Press, Madison, Wisc.

Roper, T.R. and J.S. Klueh. 1996. Movement patterns of carbon from source to sink in cranberry. J. Amer. Soc. Hort. Sci. 121:846847.

Roper, T.R., E.J. Stang, and G.M. Hawker. 1992. Early season leaf removal reduces fruit set and size in cranberry. HortScience 27:75.

Roper, T.R. and N. Vorsa. 1997. Cranberry. Botany and Horticulture Hort. Rev. 21:215-249.

Steel, R.G.D., J.H. Torrie, and D.A. Dickey. 1997. Principles and Procedures of Statistics: A Biometrical Approach. 3rd Edition. McGraw-Hill, New York, NY

Strik, B.C., T.R. Roper, C.J. DeMoranville, J.R. Davenport, and A.P. Poole. 1991. Cultivar and growing region influence return bloom in cranberry uprights. HortScience 26:1366-1367.

Vanden Heuvel, J.E. and J.R. Davenport. 2005. Effects of light, temperature, defoliation and fruiting on carbon assimilation and partitioning in potted cranberry. HortScience 40:1699-1704. 